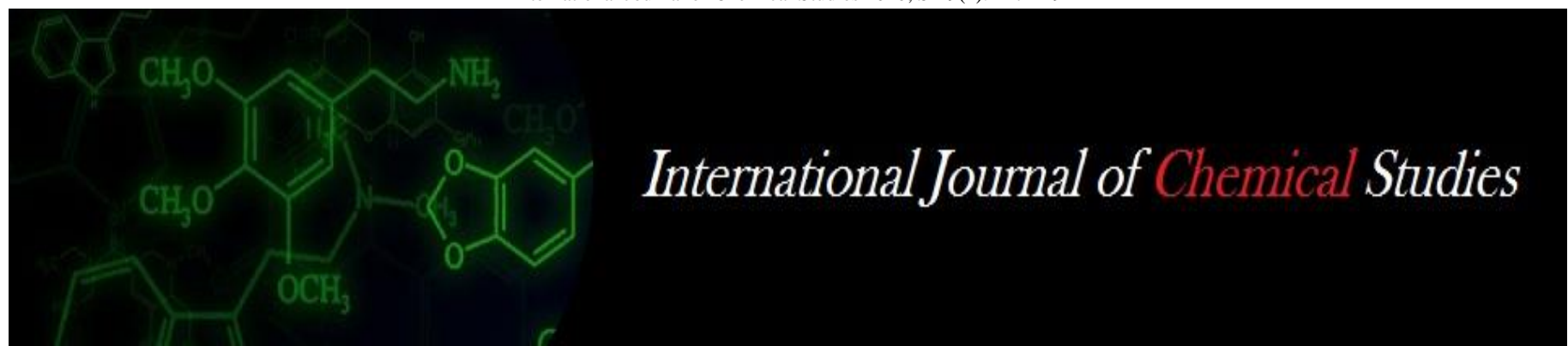

P-ISSN: 2349-8528

E-ISSN: 2321-4902

www.chemijournal.com

IJCS 2021; SP-9(1): 147-149

(C) 2021 IJCS

Received: 21-11-2020

Accepted: 24-12-2020

Ria Rani Laha

M.Sc. Horticulture, Rama

University, Faculty of

Agricultural Science and Allied

Industries, Rama University,

Mandhana, Kanpur, Uttar

Pradesh, India

Krishna Kumar Mishra

Assistance Professor, Rama

University, Faculty of

Agricultural Science and Allied

Industries, Rama University,

Mandhana, Kanpur, Uttar

Pradesh, India

M Sekhar

M.Sc. Agronomy, SHUATS, Faculty of Agricultural Science and Allied Industries, Rama

University, Mandhana, Kanpur,

Uttar Pradesh, India
Corresponding Author: Krishna Kumar Mishra Assistance Professor, Rama university, Faculty of Agricultural Science and Allied Industries, Rama University, Mandhana, Kanpur, Uttar Pradesh, India

\section{Impact of integrated nutrient management on growth and quality in chilli (Capsicum annum. var. Ankita N.S-015)}

\author{
Ria Rani Laha, Krishna Kumar Mishra and M Sekhar
}

DOI: https://doi.org/10.22271/chemi.2021.v9.i1c.11553

\begin{abstract}
The present research work on evaluation Effect of Integrated Nutrient Management in Chilli (Capsicum annum. Var. Ankita N.S-015).

Global awareness of human \& soil health and environmental issues has attracted the vegetable growers to adopt alternate farm practices. Therefore, an experiment was conducted at Agricultural Research Farm, Faculty of Agricultural Science \& Allied Industries, Rama University, Mandhana, Kanpur (U.P.) during Rabi, 2019-2020. The test crop chilli (var. Anlita N.S-015) received 7 different treatments namely; absolute control (T0), 100\% RDF of NPK (T1), 100\% RDF of NPK + Azospirillum (T2), 100\% RDF of NPK + PSB (T3), 50\% RDF of NPK + Azospirillum + PSB (T4), 50\% RDF of N + 100\% RDF of PK + Azospirillum + PSB (T5), 50\% RDF of P + 100\% RDF of NK + Azospirillum + PSB (T6). Each treatment was replicated three times and imposed over a statistically laid out field in randomized block design (RBD) at a plot size of $3 \mathrm{~m} \times 3 \mathrm{~m}$ with 3 replications and total no. of plots 21 . Ankita N.S-015 variety of chilli was transplanted at a spacing of $60 \mathrm{~cm} \times 30 \mathrm{~cm}$. Results revealed that the treatment $\mathrm{T} 2$ (100\% RDF of NPK + Azospirillum) recorded maximum values for plant height $(74.250 \mathrm{~cm})$, number of primary brunches (8.100), number of secondary brunches (8.090), Number of Tertiary branches (5.480), Days to Anthesis (45.450), Days to Flowering (54.600). The maximum uptake of Nitrogen, Phosphorous and potassium was also observed in treatment $\mathrm{T} 2$ followed by $\mathrm{T} 3$ and $\mathrm{T} 1$. The results indicated that soil test based recommended dose of fertilizer (50\%) combined with Azospirillum + PSB was the best treatment for getting higher yield and return from.
\end{abstract}

Keywords: NPK, Azospirillum, PSB, Chilli

\section{Introduction}

Chilli (Capsicum annum L.) is one of the important vegetable-cum-spice crops of India. It belonging to family Solonaceae having chromosome no $2 n=24$. It has different types of protein, vitamin, and ascorbic acid contents and is a good source of medicinal potential. The crop is very important for agricultural economy and is used in processing industries. India is the largest producer, consumer and exporter of chilli, which con-tribute to $25 \%$ of total world's production. In India, chilli is grown in almost all the states across the length and breadth of the country. In India the most important chilli growing states are Karnataka, Tamil Nadu, Orissa, Maharashtra, Rajasthan and West Bengal. Andhra Pradesh is the largest producer of chilli in India, contributes about $30 \%$ to the total area under chilli, followed by Karnataka (20\%), Maharashtra (15\%), Orissa (9\%), Tamil Nadu (8\%) and other states contributing $18 \%$ to the total area under chilli (Kumar, 2013). It is pre-dominantly popular for its green pungent fruits, which is used for culinary purpose. Chilli production has to be increased primarily from enhancing the productivity with a combination of high yielding plant types (Paul et al., 2013), standard agronomic practices like seed priming (Maiti et al., 2013) and balanced plant nutrition attained through integrated nutrient management (INM). Since chemical fertilizer alone will not be able to sustain the productivity, integrated use of all potential sources of plant nutrients seems to be the only option to maintain soil fertility and crop productivity. 


\section{Materials and Methods}

The experiment was conducted at Research Farm, Faculty of Agricultural Sciences and Allied Industries, Rama University, Kanpur in year September 2019 to March 2020 in three consecutive Rabi season. The experiment was laid out in randomized block design (RBD) in three replications with 7 treatments. The variety Ankita N.S-015 has been developed at Chandra Shekhar Azad University of Agricultural \& Tech. (Kanpur). The experiment was started on 29th September, 2019. Nursery was raised under low cost polyhouse. The experiment was conducted in plots of size $3.2 \times 3.4 \mathrm{~cm}$ with a spacing of $60 \times 30 \mathrm{~cm}$. The details of the treatment are T1: control, T2: $100 \%$ RDF of NPK, T3: $100 \%$ RDF of NPK + Azospirillum, T4: 100\% RDF of NPK + PSB, T5: 50\% RDF of NPK + Azospirillum + PSB, T 6: 50\% RDF of N + 100\% $\mathrm{RDF}$ of $\mathrm{PK}+$ Azospirillum + PSB, T7: 50\% RDF of $\mathrm{P}+$ $100 \%$ RDF of NK + Azospirillum + PSB. The observation were taken on different growth parameters, quality parametars, and yield and yield attributing characters like plant height $(\mathrm{cm})$, number of branches/plant, First flower initiation (Days), First fruit harvest (Days), number of fruits per plant, Total Soluble Solids (TSS) ${ }^{\circ}$ Brix, Vitamin C, Number of fruits, Yield per plot, Green pods yield, Number of green pods.

\section{Results and Discussion \\ Growth contributing parameters}

The growth parameters of chilli were significantly influenced by different nutrient management practices and biofertilizers amendments at all the growth parameters are presented in the (Table 1). Significabtly higher plant height $(74.250 \mathrm{~cm})$ was recorded in the plants which supplied with $100 \%$ RDF of $\mathrm{NPK}+$ Azospirillum (T3) and it was on par with T1 $(70.880 \mathrm{~cm})$, T6 $(68.470 \mathrm{~cm})$, T5 $(68.470 \mathrm{~cm})$. Whereas lower plant height was recorded in $\mathrm{T} 1(60.650 \mathrm{~cm})$. The results of present investigation are in close conformity with the findings of (Deshpande et al., 2010) ${ }^{[7]}$.

The application of $100 \%$ RDF of NPK + Azospirillum (T3) resulted in significantly higher number of primary, secondary, Tertiary branches per plant $(8.100,8.090$ and 5.480). Whereas lower number of primary, secondary and Teatiary branches per plant ware recorded in $\mathrm{T} 1(5.750,5.750$ and 3.850). The findings are in line with the results of Medhe et al., (2010) ${ }^{[5]}$, Deshpande et al., (2010) ${ }^{[7]}$.

Days of first flower initiation for chilli cultivars showed a significant variation. The maximum days of first flowering T2 (51.600days) which was statistically identical with T3 (51.850 days), while late from T0 (49.900 days) (Table 1.).

Table 1: Days of first flower initiation for chilli cultivars showed a significant variation

\begin{tabular}{|c|c|c|c|c|c|c|}
\hline Treatments & $\begin{array}{c}\text { Plant } \\
\text { height }\end{array}$ & $\begin{array}{c}\text { No. of primary } \\
\text { branches }\end{array}$ & $\begin{array}{c}\text { No. of secondary } \\
\text { branches }\end{array}$ & $\begin{array}{c}\text { No. of tertiary } \\
\text { branches }\end{array}$ & $\begin{array}{c}\text { Days to } \\
\text { anthesis }\end{array}$ & $\begin{array}{c}\text { Days to flowering } \\
\text { per plant }\end{array}$ \\
\hline Control & 60.650 & 5.750 & 5.750 & 3.850 & 41.200 & 49.900 \\
\hline 100\%. RDF of NPK & 70.880 & 7.750 & 7.740 & 5.300 & 43.100 & 52.200 \\
\hline 100\% RDF of NPK + Azospirillum & 74.250 & 8.100 & 8.090 & 5.480 & 45.450 & 54.600 \\
\hline 100\% RDF of NPK + PSB & 69.170 & 7.550 & 7.560 & 5.100 & 42.800 & 51.850 \\
\hline $\begin{array}{c}\text { 50\% RDF of NPK + Azospirillum + PSB } \\
\text { 50\% RDF of N + 100\% RDF of PK + Azospirillum + } \\
\text { PSB }\end{array}$ & 68.100 & 6.990 & 6.980 & 4.620 & 41.850 & 50.700 \\
\hline $\begin{array}{c}500 \% \text { RDF of P + 100\% RDF of Nk + Azospirillum + } \\
\text { PSB }\end{array}$ & 63.870 & 7.450 & 7.450 & 5.000 & 42.950 & 52.100 \\
\hline C.D. & 5.7822 & 0.8192 & 1.1156 & 0.5267 & 1.9907 & 2.2811 \\
\hline SE(m) & 1.8769 & 0.2658 & 0.3619 & 0.1713 & 0.6463 & 0.7405 \\
\hline SE(d) & 2.6539 & 0.3759 & 0.5118 & 0.2422 & 0.9138 & 1.0471 \\
\hline
\end{tabular}

\section{Quality parameter}

The findings of the experiment indicated beneficial effect of integrating NPK fertilization with various organic manures as well as biofertilizers on quality attributing characters of chilli. Quality of chilli is generally evaluated in terms of TSS and vitamin $\mathrm{C}$ (Table. 2). It is observed that combination treatment of $100 \%$ RDF of NPK + Azospirillum significantly increased the TSS (5.950 ${ }^{\circ}$ Brix) and Vitamin C (129.750mg). Similar findings were also reported by Mahmood and Amara
(2000) ${ }^{[4]}$ who found that biofertilizers application combined with 50\% RDF gave the highest TSS and vitamin C content as well as nutrient content of fruit. Rofi et al., (2002) ${ }^{[8],}$ Chumyani et al., (2012) ${ }^{[1]}$ observed that application of $50 \%$ NPK $+50 \%$ FYM + Biofertilizers recorded maximum TSS and vitamin $\mathrm{C}$ in radish and tomato. Vimera et al., (2010) also reported maximum vitamin $\mathrm{C}(117 \mathrm{mg} / 100 \mathrm{~g})$ by the application of $50 \% \mathrm{NPK}+50 \% \mathrm{FYM}+$ Biofertilizers in king chilli.

Table 2: Quality of chilli is generally evaluated in terms of TSS and vitamin C

\begin{tabular}{|c|c|c|}
\hline Treatments & TSS $^{0}$ Brix & Vitamin C \\
\hline Control & 4.930 & 116.100 \\
\hline $100 \%$. RDF of NPK & 5.600 & 131.870 \\
\hline $100 \%$ RDF of NPK + Azospirillum & 5.950 & 129.750 \\
\hline $100 \%$ RDF of NPK + PSB & 5.510 & 119.160 \\
\hline $50 \%$ RDF of NPK + Azospirillum + PSB & 5.060 & 126.690 \\
\hline $50 \%$ RDF of $\mathrm{N}+100 \%$ RDF of PK + Azospirillum + PSB & 5.380 & 118.920 \\
\hline $50 \%$ RDF of $\mathrm{P}+100 \%$ RDF of Nk + Azospirillum + PSB & 5.050 & 0.000 \\
\hline C.D. & 0.2017 & 6.7233 \\
\hline $\mathrm{SE}(\mathrm{m})$ & 0.0658 & 2.1824 \\
\hline SE(d) & 0.0931 & 3.0859 \\
\hline
\end{tabular}




\section{Yield and yield attributes}

The findings of the experiment indicated beneficial effect of integrating NPK fertilization with various organic manures as well as biofertilizers on yield and yield attributing characters of chilli (Table.3). Application of $100 \%$ RDF of NPK + Azospirillum maximum result in all yield attributing characters such as number of green pods (7.830), green pods yield (201.650). The average number of pods per plant is an important yield component to achieve high green chilli yield.
The average number of pods per chilli plants that were grown in different inorganic and organic fertilizer combinations were increased at 150 DAT rhan those at 120DAT. However, it did not show any significant different $(p>0.01)$ with T5 where the average numbers of 10.5 pods per plants were observe at 120 DAT. This result in conformity with [Kendaragama, 1999] who observed similar results in response of tomato and chilli to application of organic materials.

Table 3: The findings of the experiment indicated beneficial effect of integrating NPK fertilization with various organic manures as well as biofertilizers on yield and yield attributing characters of chilli

\begin{tabular}{|c|c|c|}
\hline Treatments & No. of green pods & Green pods yield \\
\hline Control & 5.110 & 165.450 \\
\hline 100\%. RDF of NPK & 7.180 & 187.900 \\
\hline 100\% RDF of NPK + Azospirillum & 7.830 & 201.650 \\
\hline 100\% RDF of NPK + PSB & 7.070 & 185.080 \\
\hline 50\% RDF of NPK + Azospirillum + PSB & 6.490 & 169.940 \\
\hline 50\% RDF of N + 100\% RDF of PK + Azospirillum + PSB & 6.900 & 180.600 \\
\hline 50\% RDF of P + 100\% RDF of Nk + Azospirillum + PSB & 6.470 & 169.380 \\
\hline C.D. & 1.1527 & 17.3029 \\
\hline SE(m) & 0.3742 & 5.6165 \\
\hline SE(d) & 0.5291 & 7.9418 \\
\hline
\end{tabular}

\section{References}

1. Singh AK, Chumyani Kannaujia SP, Singh VB. Effect of integrated nutrient management on growth, yield and quality of tomato (Lycopersicon esculentum mill). Journal of Soil and Corps 2012;22(1):5-9.

2. Kendragama KMA. Response of tomato and chilli to application of four organic materials on an alfisol. Annals of the Sri Lanka, Department of Agriculture 1999;1:108113.

3. Mehraj H, Tamima H, Chowdhury MSN, Howlader MF, Jamal Uddin AFM. Study on Morpho-physiological and Yield Performance of Four Chilli (Capsicum spp.) Lines. Journal of Bioscience and Agriculture Research 2014;2(1):01-07.

4. Mahmood HAF, Amara MAT. Response of tomato to biological and mineral fertilizers under calcareous soil conditions. Bulletin of Faculty Agriculture, Cario University 2000;51:151-174.

5. Medhe NK, Gawade BV, Randive SN, Temkar BG. Effect of integrated nitrogen management on yield and economics of green chilli (Capsicum annuum L.) production. Green Farming 2010.

6. Kanaujia P, Singh SP, AK, Singh VB. Integrated nutrient management for quality production of radish (Raphanus sativus L.) in acid Alfisol. Journal of Soils and Crops 2010;20:1-9.

7. Deshpande R, Tamgadge RP, Deshmukh SA, Deshmukh S. Effect of organic and inorganic manures on growth and yield of chilli. Inter. J For Crop Improvement 2010;1:146-148.

8. Rofi M, Narwadkar PR, Prabu T, Sajindranath AK. Effect of organic and inorganic fertilizers on yield and quality of tomato. Journal of Soils and Crops 2002;12:167-169. 